\title{
7 Health, Healing, and the Social Body in Medieval Iceland
}

\author{
Christopher Crocker and Yoav Tirosh
}

\section{Introduction}

For good reason, activists and scholars have long advocated for an understanding of disability beyond its traditional modern conceptualisation as an individual problem that could only be solved - or remain unsolved following medical intervention (Shakespeare 2014, Beaudry 2016, Sigurjónsdóttir and Rice in this volume). The consequent emergence of disability studies as an academic discipline saw the rejection of a strictly medicalised conceptualisation of disability, focusing instead on how atypical bodies and minds are subject to myriad social, political, cultural, and economic factors as well as an impetus for cultural production. However, some scholars have challenged approaches to the subject that seem to repudiate any exploration of the physiological dimensions of disability. Shakespeare (2014) for example, has suggested that "health needs of disabled people are rarely taken into account in disability studies" (p. 83) and that the "[f]ailure to meet general or impairment-related health needs is itself a disabling barrier" (p. 83). Following this line of thought, those who make use only of those theorisations that regard disability and health concerns as mutually exclusive issues run the risk of obscuring crucial interactions and intersections between the two.

Scholars exploring disability in the premodern past, while commonly adopting a predominantly socio-cultural approach, are perhaps more easily able to avoid disregarding such interactions and intersections. This is so not because medical care is an entirely modern innovation but rather due to the modern phenomenon of siloing knowledge systems resulting in the tendency to ideologically constitute scientific understanding, including medical science, as utterly distinct from or, sometimes, as directly opposed to other discourses regarding the body. During the Middle Ages, for example, common conceptualisations of the body were frequently physiological but also simultaneously incorporated emotional, legal, moral, mythological, paranormal, theological, and other dimensions (Horden 2009, Frog 2019, Hartnell 2019). Thus, scholars who adopt an approach inspired by a disability studies perspective when examining matters of health, illness, and 
healing care during this period are arguably better equipped than those working within the confines of a traditional history of medicine approach, particularly when dealing neither with physical evidence nor with source material that assumes a decidedly medical register.

With this in mind, the present chapter deals with issues of health, illness, and healing care in medieval Iceland, particularly as expressed through the prism of the Íslendingasögur (Sagas of Early Icelanders). This collection of texts, dating to the 13th, 14th, 15th centuries, constitutes a literary form of history mediated through oral traditions, which combines inherited cultural memories with creative historical interpretations of the past (Jakobsson 2015, Crocker et al. in this volume). These sagas are valuable sources regarding prevailing, but also variable, ideologies and mentalities concerning health, illness, and healing care in medieval Iceland. Bodies or minds perceived to be healthy in the sagas, and consequently also their unhealthy counterparts, are not only represented as physiological phenomena but are also as reflections of a variety of socio-cultural factors. This is exemplified in the Old Icelandic terms heill and heilsa, which refer to both "health" and to "wholeness," with the later sense of the term encompassing not only physiological wholeness but also the ability to fulfil one's prescribed social role. As such, health, illness, and healing care in the sagas are best explored not only as individual but as social phenomenon as well. The unhealthy body in particular either provokes or fails to provoke a variety of actions or responses from the community and, thus, operates as a medium through which aspects of the body's inevitably social nature become evident.

\section{Healing the body}

In contrast to the case-specific insights provided by the surviving premodern physical evidence (Collins 2018, Hoffman 2019, Haraldsson in this volume, Kristjánsdóttir and Walser III in this volume) or handbooks listing specific treatments for different kinds of illnesses (Larsen 1931), the medieval sagas refer to a broader awareness of both practical and theoretical understandings of the body and are concerned with how this knowledge was applied, as well as who had access to this knowledge and practice. Attempts to draw distinctions, for example, between certain healing practices such as learned observations, divine intervention in the form of saintly miracles, and religio-magical practices may have existed in the medieval North (Simek 2019, McDougall 1992, Whaley and Eliot 1994). Yet, surviving written sources suggest that matters concerning health, illness and healing care were often simultaneously mediated through foreign medical doctrines, corresponding folk traditions, religious beliefs, ideas about emotions, and perceptions of the paranormal.

A text found in the early 14th century manuscript known as Hauksbók, for example, bears the title "Af natturu mannzins ok blodi" (On the nature 
of man and blood). It contains a short summary of humoral theory, which originated in antiquity and was widely circulated throughout the Middle Ages, that suggested one's general disposition, health, and emotions were determined by a balance or imbalance of certain bodily fluids, which could also be subject to change as one ages (Jónsson and Jónsson 1892-96, p. 181-82). The physiological portion of the text, which may be an Old Icelandic translation deriving from a medieval Latin text known as Epistula Vindiciani (Vindician's letter), is preceded by a tract on God's creation of the world, aspects of its nature, climate, and geography, culminating with the creation of Adam (Jónsson and Jónsson 1892-96, p. 180-81, Porgeirsdóttir 2018, p. 51-60). The arrangement of the text, which makes a seamless transition between theological and physiological or medical ideas, indicates that the two are intended to be seen as intimately connected and even inseparable from one another. References to and perhaps more subtle echoes of humoral theory have also been detected in several other medieval Icelandic texts, including some of the more well-known sagas.

Scholars have argued, for example, that versions of Egils saga SkallaGrímssonar, Fóstbraðra saga, and Bandamanna saga, among other sagas, include passages that suggest a familiarity with traditional humoral theory by way of imported Latin literary influence (Reichborn-Kjennerud 1936, p. 20-26, Lönnroth 1965, Kristjánsson 1972, p. 240-47, Høyersten 1998, Tirosh 2014, Høyersten 2015, Kanerva 2015, p. 111-13, Porgeirsdóttir 2018, p. 49-50). However, some have countered this claim, or at least claims about the magnitude of foreign influence on ideas concerning health, illness, and healing in Iceland during the Middle Ages (Hallberg 1965, Kanerva 2015). Kirsi Kanerva (2015), for instance, has emphasised the persistence in medieval saga writing of folk traditions concerning health, illness, and healing in medieval Iceland, which were inseparable from moral or religious matters, emotional practices, and encounters with the paranormal (Erlingsson 1996, Hall 2009, Kanerva 2013, Kanerva 2014, Porgeirsdóttir 2015). More than this, as mentioned above, the body in the sagas - including its perceived unhealthy or un-whole forms - is a social phenomenon, which can be illustrated using a striking example from the aforementioned Egils saga Skalla-Grimssonar.

In a brief anecdote in the saga, a kona sjúk (ill woman) named Helga Porfinnsdóttir becomes bedridden but unable to sleep. Helga and her condition are variously described using the terms pungliga haldin (very ill), hamstoli (crazed), langan vanmátt (long waning strength), and kröm mikil (great wasting disease). At her father's request, the saga's poet protagonist Egill offers to help. He first advises that her bedclothes be changed, whereupon he discovers runes carved on a whalebone had been placed under her bed. Helga's father suggests that these runes were placed there by the son of a neighbouring farmer as an attempt to heal Helga's's illness. Egill casts the whalebone into the fire, while he simultaneously chastises in verse those who engage in such practices without having the proper knowledge 
to do so. He then places carved runes of his own under the bed. After only a short time a rapid change comes over Helga and she claims that she "var pá heil, en pó var hon máttlítil" (was now healthy, although she had little strength). Both Egill and the narrative quickly move on, but sometime later, when Egill returns to the same farm, the saga relates that "Helga ... var pá á fótum ok heil" (Helga ... was then on her feet and healthy) (Nordal 1933, p. 229-30). In the meantime, it had come out that the man who had carved the runes Egill had thrown into the fire intended to seduce Helga, but his lack of knowledge had led to her become ill instead.

The saga is somewhat equivocal about the cause of Helga's illness. Its onset initially seems to precede but might also be a consequence of the runes carved by her unwelcome suitor. In any case, her illness and its treatment are connected to both emotions and specialised or esoteric knowledge. Physical evidence attests to the reality in the medieval North of the use of runic carvings to deal with illnesses and healing (Jesch and Lee 2020). Yet, the narrative construction of Egill's intervention may have also been influenced by scriptural and hagiographical narrative traditions (Grønlie 2017, p. 88-90). In fact, rather than the specific details of the treatment he provides, the focus is firmly placed on him possessing such rare knowledge and not on the details of the knowledge itself. Moreover, the saga relates how Helga's father compensates or rather reciprocates Egill not only through the hospitality he provides, but also by accompanying him and his companions as they travel through hostile territory (Nordal 1933, p. 229-31). Egill's well-timed application of his specialised knowledge can be read as an extension of gift-giving practices common in medieval Iceland and Scandinavia (Pálsson 2015, Sigurðsson 2017, Barriero forthcoming). In this instance, his knowledge functions as a reciprocal good that can be shared and, through its sharing, it establishes a meaningful homosocial bond between the two men.

This brief anecdote, culminating with Helga's return to heil( $l$ ) (health or wholeness) underscores how matters concerning health, illness, and healing care in medieval saga writing frequently concern more than the individual body. Whether originally caused or only exacerbated by the actions of her unwanted suitor, Helga's illness or, indeed, un-wholeness is explicitly connected to the threat of an unwanted and illicit love affair. Furthermore, although the saga makes no further mention of Helga beyond this point, the emphasis placed on this aspect of her illness seems to suggest that her return to heil(l) likely also coincides with a revived opportunity for Helga and her family to establish new social bonds through marriage with a more appealing suitor (Schulman 1997, Karras 2003). It is also worth noting that Egill's crucial intervention was not, however, that of a sought after professional but of a man possessing the required specialised skills who happened to be in the right place at the right time. Yet, his specialised skills also require the availability of unhealthy bodies to prove their efficacy and value. Although the saga provides no insight toward the motivation 
behind Egill's actions, the way Helga's father compensates him falls entirely within the reciprocal culture depicted throughout medieval saga writing. Ultimately, though contingent upon the presence of an unhealthy body, this brief episode is as much or arguably even more interested in the broader social actions that encompass the events than with the specific details of Helga's illness and her individual experience of the ordeal.

\section{The whole body}

An episode found in Fóstbraðra saga, one concerning the poet bormóðr Bersason, similarly stresses how illnesses in the sagas function as a lens through which aspects of social nature of the body become visible. The episode begins when Pormóðr is visited in a dream by a woman named porbjorg kolbrún (coal-brow) for whom he had composed a series of flattering verses. In the dream, Porbjorg chastises bormóðr for reworking and rededicating the verses to a woman named bórdís. She threatens to inflict severe augnaverkr (eye-pain) upon him, such that his eyes will burst out of his head and tells him that he will "aldregi heill verða" (never be heill again) (Pórólfsson and Jónsson, 1943, p. 174-177), unless he publicly admits to his transgression and returns the verses to their original form. Sure enough, Pormóðr awakens with severe pain in his eyes prompting his father Bersi to remark aphoristically "Eigi er sá heill, er í augun verkir" (One is not heill, who has pain in his eyes) (Pórólfsson and Jónsson, 1943, p. 174-177). Bersi advises Pormóðr to heed the warning and also reminds pormóðr of an earlier wound he had suffered. That wound, which rendered him orvendr (left-handed) for the rest of his life, followed his previous seduction of the same Pórdís, whose favour he had tried to win back by rededicating the verses to her. Echoing, but also somewhat contradicting Porbjorg's warning, Bersi suggests that his son already "verðr aldri heill maðr" (will never be a healthy man again) (Pórólfsson and Jónsson, 1943, p. 174-177), not only if he fails to reverse the course of his eye-pain but also on account of his earlier wound.

In any case, when Pormóðr returns the verses to their original form and again dedicates them to Porbjǫrg, the saga states that "verðr hann pá alheill pess meins" (he then fully recovered from this injury) (Dórólfsson and Jónsson 1943, p. 174-77). More than simply a physiological phenomenon, however, in this and many other instances in medieval saga writing, the onset of augnaverkr (eye-pain), frequently following the experience of a paranormal dream, is commonly connected to various kinds of perceived moral transgressions, whether interpersonally, socially, or spiritually (Kanerva 2013, Crocker 2019, p. 42-50, Crocker 2020). Pormóðr's transgression seems to relate to his fickleness and promiscuity, reflecting his perceived "socially abnormal relationships with women" (Merkelbach 2019, p. 85). Although his augnaverkr is quickly alleviated, the likely loss of vision, and perhaps also the facial disfigurement he would have experienced had he not met 
Porbjorg's demands, would likely serve as visible markers of his moral turpitude. Thus, the saga seems to suggest that, in medieval Iceland, otherwise unexplained eye injuries and ensuing visual impairments could be regarded not only as discernible physiological differences but also as manifestations of their bearer's flawed moral character, which could invite social stigma or other prejudicial treatment.

As in the example from Egils saga Skalla-Grimssonar, the concept of heill encompasses more than the strictly physiological in this episode. Pormóðr's father uses the term when he tells his son that he will never be heill (healthy or whole) again in reference to an injury the lasting effect of which was the loss of manual dexterity in his right arm or hand. John Sexton $(2010,2020)$ contends that assessments of permanently injured male bodies in the sagas are not always constituted as "a permanent redefinition of the injured person," whether conveyed through the same phrase Dormóðr's father uses or, for example, a term such as óvigr (unable to fight) (p. 155-56). Furthermore, Edna Edith Sayers, published as (Bragg 2004), argues that, rather than negative social stigma, such injuries could also be read as "the proud tokens of ... properly reckless battle conduct," at least in some instances (Bragg 2004, p. 92, p. 241-42, Sexton 2010, p. 154-57, Künzler 2016, p. 259-65). Yet, in Pormóðr's case, as in several others, there is little evidence in the text, beyond the brief exchange he shares with his father, to determine how Pormóðr and the society around him made sense or interpreted his enduring "un-wholeness" in the context of the martial society depicted in the sagas.

The perhaps conspicuous silence surrounding Pormóðr's injury in its immediate aftermath and the loss of manual dexterity that follows may, on the other hand, reflect a broader cultural inability to properly address and verbalise the individual and collective trauma that pervades the violent society depicted in medieval saga writing (Heiniger 2020, Tulinius 2018a, Tulinius 2018b, Poilvez 2020). With this in mind, it is worth mentioning that the slave, Kolbakr, who had inflicted the wound on Pormóðr at Pórdís's mother Gríma's behest, is outlawed but manages to escape from Iceland. The saga makes a point to explain that bormóðr never received "meiri sæmð síns áverka en sekðir Kolbaks" (more redress for his injury than Kolbakr's conviction) (Pórólfsson and Jónsson 1943, p. 169). Thus, more than just a physical difference, the injury acts as a lasting mark of Pormóðr and his father's shame for having failed "to extract justice from a woman householder and her slave" (Bragg 2004, p. 226). Still, despite several reminders and expressions of his own sense of self-doubt, the narrative suggests that Pormóðr's lasting injury can ultimately be redefined in a way that renders him capable of living out a traditional hero's arc. This redefinition, however, does not follow any physical change but rather results from an encounter with a man named Gestr, a mysterious and seemingly Odinic figure, as well as Pormóðr's entry into the saintly King Óláfr helgi’s service (Bragg 2004, p. 231-33, Grønlie 2017, p. 236-43, Merkelbach 2019, 
p. 86-89). Keeping this in mind, it is likely no coincidence that Pormóðr's final act in the narrative is to die in battle while heroically defending a group of injured warriors in a barn that has been turned into a makeshift field hospital.

Returning to the aftermath of Pormóðr's dream encounter with Porbjorg, it is worth recalling that his primary identity in the saga is not as a warrior but as a poet, as encoded in his nickname kolbrúnarskáld (coal-brow's poet). His "verbal acuity" has, in fact, been interpreted as a kind of compensation for his permanently injured body (Bragg 2004, p. 232). Even if such an interpretation risks overreading that aspect of the saga, the eye-pain, and the threat of vision loss that Porbjorg inflicts upon him is much more than just a physical threat. As mentioned above, it could simultaneously serve as an outward marker of Pormóðr's morally flawed character. Even more than this, the episode illustrates that Pormóðr's body is deeply entangled with his social identity and public role as a poet. Although blindness or vision loss in literature sometime takes on a symbolic meaning in the context of poets possessing inner vision and being able to "see" what others cannot see, such symbolism is not present in Fóstbraðra saga. Instead, Pormóðr's state of heill (health or wholeness) reflects his public status as a poet and both become compromised when he violates the perceived norms of the profession. The public nature of this compromise is further underscored by the fact that Porbjorg demands not a private apology but a public admission of both the wrong he has done and a rededication of the verses he had originally composed in her honour.

\section{The social body}

In another saga, Vápnfirðinga saga, both health and access to healing care are also major components in the narrative's construction such that - to an even greater degree than the previous examples - the social nature of the body emerges as one of the saga's central, recurring motifs, only a few representative examples of which can be explored at present. After beginning by recounting a few of the exploits of a young Brodd-Helgi porgilsson, the saga focuses primarily on the relationship he shares with Geitir Lýtingarson and, later, the complex relationship between their sons porkell Geitisson and Bjarni Brodd-Helgason. Geitir and Brodd-Helgi are childhood friends from the North-East of Iceland who grow to become powerful men in the region and consolidate their friendship through a marriage between Brodd-Helgi and Geitir's sister Halla. Eventually, however, Geitir and Brodd-Helgi's relationship turns sour following a financial dispute, which coincides with Halla's health taking a turn to the worse. There is no explicit indication that the onset of Halla's vanheilsa (waning health, or perhaps chronic illness) is a result or symbolic reflection of the withering of her husband and brother's close friendship, but the correlation between the two events is slightly conspicuous. 
In any case, when Halla makes Brodd-Helgi aware of her illness, he makes overtures of love and assures her that he will remain with her "meðan okkart líf vinnsk" (until the end of our lives) (Jóhannesson 1950, p. 36). Yet, despite these theatrics, he quickly finds a new, younger, and presumably healthier wife named Porgerðr silfra (silver). Halla is therefore denied the love and care of her husband due to her illness, but the narrative also makes clear that Brodd-Helgi's behaviour was viewed negatively by the people of the district due to Halla's popularity. A husband whose wife was grievously ill was clearly expected to stay by her side, a duty that Brodd-Helgi's fails to carry out. However, one day when her brother Geitir is away from home, Halla sends for Helgi to come visit her. Upon his arrival, "Hon bað hann, at hann skyldi sjá meinit. Hann gerði svá, ok kvazk honum pungt hugr um segja. Hann hleypir út vatni miklu ór sullinum, ok varð hon máttlítil eptir petta" (She asked him to have a look at her sore. He did this, and said it seemed a grave matter indeed. He pushes much water out of the boil, and she became exhausted after this) (Jóhannesson 1950, p. 44). Halla then asks Brodd-Helgi to stay for the night, but he refuses. She scolds him for the way he has treated her, after which he leaves, and a few days later, she dies. Following Halla's death, the friendship between Brodd-Helgi and Geitir is irreparably dissolved. Sometime after this, Brodd-Helgi is killed, either by Geitir or more likely one of his men, with the killer's precise identity missing in the extant manuscripts of the saga.

As with the cases of Helga who is successfully healed by Egill, the promiscuous poet bormóðr, and that of Halla and Brodd-Helgi, whose treatment is less successful than Egill's, sagas often put a spotlight on health and illness in interactions involving love. In Bjarnar saga Hitdœlakappa, for example, Pórðr Kolbeinsson vanquishes his long-time foe Björn in battle, afterwards cutting off his head. The gloating Pórðr informs his wife Oddný, who had been having an affair with Björn, of the death, and presents her with her decapitated lover's necklace. Oddný does not take this news very well, and collapses when she sees the necklace, and is afterwards like Halla - struck with mikil vanheilsa (severely waning health, or perhaps chronic illness) from which she never recovered. Her death, however, is not imminent, but the narrative stresses that she lost all joy in life and mourned Björn until the end of her surprisingly long life. Yet, bórðr goes to great lengths to help his wife through her mental and physical anguish. As the saga describes, "Henni pótti sér pat helzt ró, at hon sæti á hestbaki, en Pórðr leiddi undir henni aptr ok fram, ok gerði hann pat, at honum pótti stór mein á vera, en vildi við leita at hugga hana" (It was most soothing for her to sit on horseback with Pórðr leading her back and forth, and he did this, though it was very painful for him, but he wanted to comfort her) (Nordal and Jónsson 1938, p. 207). Despite putting himself in a painful and clearly humiliating situation, Pórðr takes actions to comfort his wife although her torment derives from the death of a lover whom she loved more than him. This kind of behaviour may have been expected from a husband and makes 
Brodd-Helgi's quick dismissal of his wife when she becomes ill seem even less socially acceptable. Even more than this, in contrast to Pórðr, the poor treatment that he subjects Halla to perhaps even plays a role in limiting the effectiveness of the treatment he attempts to provide her with.

Following Brodd-Helgi's death, his son Bjarni kills his uncle Geitir as revenge, though he immediately regrets the act. Geitir's son and Bjarni's cousin, Porkell, soon after returns to Iceland after a sojourn abroad, and embarks on a lacklustre vengeance attempt. At this point an important new figure is introduced into the saga named Porvarðr laknir (the healer): "Hann var vinsæll, ok var pá kallat, at hann væri beztr læknir í heraði" (He was popular, and it was thought that he was the best healer in the district) (Jóhannesson 1950, p. 53). On two occasions, Porvarðr foils Porkell Geitisson's attempts to avenge his father's death, in one instance by encountering Porkell's spy after treating a neighbour with a broken leg. Sometime afterwards, Geitir gathers a band to attack Bjarni and the saga relates that "Porkell var lítt heill jafnan ok tók opt bráđa sótt" (Porkell was always of poor health, and was often suddenly ill) (Jóhannesson 1950, p. 57). The morning of the planned attack on Bjarni, echoing the words of his aunt Halla, he tells his posse that the sally will have to be delayed due to his vanheilsa (waning health, or chronic illness) and insists that it cannot happen without him. They scold him for his cowardice and leave. The temporary onset of Porkell's illness delaying violence may be reminiscent of a motif that features men whose sudden illnesses or impairments stop them from committing actions that would simultaneously place their own lives in danger (Crocker 2019, p. 137-38, Walgenbach 2019). When Bjarni Brodd-Helgason and borkell Geitisson finally do meet for battle, the healer Porvarðr is (possibly, since the transmission of this scene is corrupted) present and seemingly on Bjarni's side, but he also displays a clear reluctance to participate in the fighting (Jóhannesson 1950, p. 59). The fight is interrupted before Porkell or Bjarni are killed, and the hapless avenger ends up with a severely wounded arm that leaves him óvigr (unable to fight). After Porvarðr treats everyone on Bjarni's side, Bjarni remarkably sends him to help nurse porkell back to health. This act facilitates a peace between the two kinsmen, who eventually become good friends, with Porkell even taking up residence with Bjarni when he grows old.

Throughout Vápnfirðinga saga, issues of health and illness both bring people together and tear them apart. Healing care is seen as a key to maintaining stable kinship, friendship, and even romantic ties. In the latter part of the saga, the healing specialist is the person who not only treats illnesses and injuries but also facilitates the rebuilding of broken relationships. Porvarðr laknir, while nominally working on Bjarni Brodd-Helgason's side, actively disrupts attempts at violence and avoids participating in such confrontations. His actions may be read as cowardice within this martial society but could also signal a sense authorial or social disapproval with Porvarðr functioning in the saga as a surrogate for the clergy's desire to uphold the 
Peace of God (Jakobsson 1998, Walter 1956, p. 44-56, Baldursdóttir 2002, Hollander 1961, p. 155). As in the example from Egils saga, Bjarni's overtures of friendship in sending Porvarðr to treat Porkell establish health as a reciprocal good that when exchanged creates or strengthens homosocial bonds between men. On the other hand, Brodd-Helgi's denial of affection and support for Halla, and her rapid replacement with the young widow Porgerðr, makes clear that poor health can quickly diminish the perceived value of a relationship. Despite the bond of love that still exists between them, which remains palpable during the final meeting between the two, it is no longer financially worthwhile for Brodd-Helgi to keep his marriage with Halla. For him, the pocket wins over the heart, which is perhaps also crudely and cruelly signified in his new wife's nickname, silfra (silver).

The way Vápnfirðinga saga organises its narrative around issues of health and illnesses, as in the previous examples, reflects the prominent social role the body had in medieval Icelandic society. It shows how healing care serves as a vital component in allowing people to establish or repair meaningful social bonds in the medieval Icelandic world, with access to professional care being an attraction for allies and followers. On the other hand, it perhaps also gives leverage to those with access to professional healers over their allies and opponents. If in modern society treatment for injuries and illnesses is primarily organised by a centralised authority, in medieval Iceland it was facilitated through the informal framework of kinship, friendship, and even romantic relationships, making these interactions all the more intimate. What is the clearest from Vápnfirðinga saga and apparent from other sagas too is that health and its management are often used as a distributed good; access to healing care can promote district power. There is of course a practical aspect at play here: The chieftain who makes certain that his men are in fighting form is likelier to succeed in the next martial encounter, as well as pose a more significant threat to his rivals. But one who has access to healing care also has the upper hand in terms of familial and friendship bonds; A hand which they can extend but also implicitly deny. In the case of Brodd-Helgi's treatment of Halla and the dissolution of their marriage due to her illness, Vápnfirðinga saga offers a stark reminder of how women were also commonly "exchanged as commodities" in medieval Iceland (Jochens 1991, p. 392). Yet, the narrative is not approving or even neutral in its stance, implying instead that the reading audience should agree with the prevailing public opinion in the community and see Brodd-Helgi's callous behaviour towards Halla for what it is.

\section{Conclusion}

Saga narratives, which feature plenty of violent conflicts, often dwell on the recourse given to people who have sustained physical trauma. Fóstbraðra saga ends with Pormóðr's final moments in a barn that has been reappropriated into a makeshift field hospital, a special space allocated for 
the treatment of those who have sustained battle injuries. Similarly, in one version of Ljósvetninga saga (referred to as the saga's C-redaction), when a man named Koðrán is wounded in battle, his brother Eyjólfr has his body moved so that he can receive treatment elsewhere. The specialist he is taken to is named Porvarðr læknir (the healer), like the healer that features in Vápnfirðinga saga and is possibly meant to be the same figure (Tirosh 2019, p. 159-62). When Porvarðr examines Koðrán he states that "ef Koðrán hefði kyrr verit, pá væri von í, en nú er engi" (If Koðrán had been left unmoved, then there would have been hope, but now there is none) (Guðmundsson and Helgason 1830, p. 88). Porvarðr here, as in Vápnfirðinga saga, accentuates the importance of access to proper care following the violent confrontations described in the sagas. For the medieval denizens of this nigh-Arctic island, access to and the distribution of healing care was on the forefront of their minds as a very real concern. Lack or mishandling of it could mean death or lasting injury. Yet, the absence of a centralised authority charged with managing such treatments meant that maintaining kinship ties and alliance building were all the more vital for one's ability to maintain their health.

Matters of health, healing, and illnesses in the medieval sagas are not, however, only concerned with the aftereffects of brutal conflicts but rather permeate all corners of the society in which the drama of these narratives plays out. Still, the ways sagas deal with these matters do not welcome close comparison with modern medical systems of thought, not only on account of cultural or social differences, but because of the nature of the texts themselves, which are not medical in their register. In some instances, such as the episode concerning Pormóðr's eye-pain and potential vision loss, health and illness may even appear to function predominantly as a kind of moral index. On the other hand, in most of the other examples discussed above, health concerns or illnesses do not seem to function as literary motifs symbolizing something else about those affected, as they commonly do in other literatures. As Bérubé (2016) notes, building on the unpublished work of Alice Sheppard, they are depicted as very tangible things with "no greater semiotic significance" (Bérubé 2016, p. 48). Yet, the context provided by the sagas still imbues these occasions with plenty of meaning, much of which is centred around whether, and if so how and by whom, treatment or healing care is provided or withheld. This stems from the fact that, in medieval saga writing, rather than deferring to a "biologically defined hegemonic body image" (Frog 2019, p. 270), ideas concerning the body, its heill (health or wholeness) and healing care are inseparably embedded within a variety of cultural traditions and social structures from which a strictly physiological understanding cannot be extracted.

In the sagas, paying close attention to the phenomenon of what is perceived as an unhealthy body stresses how thoughts, practices, behaviours, and responses to the body in medieval Iceland were shaped not by something approximating or striving towards modern medical understanding 
but rather by a complex web of cultural and social ideas and values, and primarily through one's relationships with others and their community. Of course, modern bodies are not all that different, whether characterised as healthy or unhealthy, disabled, or able, with the primary difference being the modern default to read the human body as primarily a topic for biomedical inquiry (Burroughs and Ehrenreich 1993). Yet, it is also important to recognise that health and illnesses in the sagas are not exclusively interpreted through the lens of Christianity nor do they typically function at level of literary symbolism. Likely reflecting lived experiences to some degree, they are often approached from a practical and sober perspective, which includes references to what we can identify as something like medical intervention, such as the efforts of Porvarðr in Vápnfirpinga saga. Although, as in his case, the specific details of these practices often go unremarked upon in the narratives. The different meanings attached to bodies in the sagas are frequently generated not from an interest in them as individual physiological specimens because the saga body is first and foremost a social body. As documented by the examples discussed above, it is then only natural that health, illness, and healing care in the sagas are commonly things that neither originate in nor happen to an individual in isolation but rather in and to society as a whole.

\section{References}

Baldursdóttir, S., 2002. Hugmyndaheimur Vopnfirðinga Sögu: Byggingarlag sagna frá Austfjörðum. Gripla, 13, 61-105.

Barriero, S., Forthcoming. Personal memory, family memory, collective memory? The parting gifts in Egils saga, chapter 61. Scandinavian-Canadian Studies.

Beaudry, J. S., 2016. Beyond (Models of) disability?. Journal of Medicine and Philosophy, 41 (2), 210-228. Doi: 10.1093/jmp/jhv063

Bérubé, M., 2016. The secret life of stories: From Don Quixote to Harry Potter, how understanding intellectual disability transforms the way we read. London: New York University Press.

Bragg, L., 2004. Oedipus borealis: The aberrant body in old Icelandic myth and saga. Madison, NJ: Fairleigh Dickinson University Press.

Burroughs, C. B., and Ehrenreich, J. D., 1993. Introduction: Reading the social body. In: C. B. Burroughs and J. D. Ehrenreich, eds. Reading the social body. Iowa City: University of Iowa Press, 1-14.

Collins, C., 2018. Heillög Bein, Brotin Bein: Manifestations of Disease in Medieval Iceland. In: E. Connolly and S. Kunzel, eds. New approaches to disease, disability and medicine in Medieval Europe. Oxford: Archaeopress Archaeology, 109-25.

Crocker, C., 2019. Disability and dreams in the medieval Icelandic sagas. SagaBook 43, 37-58.

Crocker, C., 2020. Narrating blindness and seeing ocularcentrism in Porsteins saga hvíta. Gripla 31, 267-292. Doi: 10.33112/gripla.31.9

Erlingsson, D., 1996. Fótaleysi göngumanns: Atlaga til ráðningar á frumpáttum táknmáls í sögu af Hrólfi Sturlaugssyni. Skírnir 170 (1), 340-356. 
Frog, J. A., 2019. Understanding embodiment through lived religion: A look at vernacular physiologies in an Old Norse Milieu. In: K. Wikström af Edholm, P. J. Rova, A. Nordberg, O. Sundqvist, and T. Zachrisson, eds. Myth, materiality, and lived religion: In Merovingian and Viking Scandinavia. Stockholm, Stockholm University Press, 269-301.

Grønlie, S., 2017. The Saint and the Saga Hero: Hagiography and early Icelandic literature. Cambridge: D.S. Brewer.

Guðmundsson, P. and Helgason, P., ed., 1830. Ljósvetnínga saga: Eptir gömlum hdr. útg. at tilhlutun hins konúngliga Norrana fornfraða félags: Sérprent úr Íslendinga sögum, 2 bindi. Copenhagen: S.L. Möller.

Hall, A., 2009. 'Pur sarripu pursa trutin': Monster-Fighting and Medicine in Early Medieval Scandinavia. Asclepio: Revista de Historia de la Medicina y de la Ciencia, 61 (1), 195-218.

Hallberg, P., 1965. (Recensioner: I. Två fakultetsoppositioner) Lars Lönnroth. Samlaren: Tidskrift för svensk litteraturhistorisk forskning 86, 157-184.

Hartnell, J., 2019. Medieval Bodies: Life, Death and Art in the Middle Ages. New York: W.W. Norton.

Heiniger, A. K., 2020. The Silenced Trauma in the Íslendingasögur. Gripla 31, 233-265. Doi: 10.33112/gripla.31.8

Hoffman, S., 2019. Place, Practice, and Pathology in Medieval Iceland: A Bioarchaeological Analysis of the Human Skeletal Remains from the Church Cemetery at Haffjarðarey (ca. 1200-1563). Thesis (PhD). SUNY: University at Buffalo.

Hollander, L. M., 1961. Saga. Untersuchungen zur nordischen Literatur und Sprachgeschichte, hrsg. Walther Baetke. Heft I: Ernst Walter, Studien zur Vápnfirðinga Saga. Halle, 1956. Heft II: Rolf Heller, Die literarische Darstellung der Frau in den Isländersagas. Halle, 1958. Heft III: Rolf Heller, Literarisches Schaffen in der Laxdoela Saga. Halle, 1960. The Germanic Review: Literature, Culture, Theory 36 (2), 154-157. Doi: 10.1080/19306962.1961.11787054

Horden, P., 2009. What's wrong with Early Medieval medicine? Social History of Medicine 24 (1), 5-25. Doi: 10.1093/shm/hkp052

Høyersten, J. G., 1998. Personlighet og avvik. En studien i islendigesagaens menneskebilde - med sarlig vekt på Njála. Bergen, NO: Universitet i Bergen.

Høyersten, J. G., 2015. Manifestations of Psychiatric Illness in Texts from the Medieval and Viking Era. Archives of Psychiatry and Psychotherapy 17 (2), 57-60. Doi: 10.12740/APP/44385

Jakobsson, Á., 2015. King Arthur and the Kennedy assassination: The allure and absence of truth in the Icelandic sagas. Scandinavian-Canadian Studies 22, 12-25.

Jakobsson, S., 1998. Friðarviðleitni kirkjunnar á 13. öld. Saga 36 (1), 7-46.

Jesch, J., and Lee, C., 2020. Healing runes. In: A. Pedersen and S. M. Sindbæk, eds. Viking encounters: Proceedings of the 18th Viking Congress. Aarhus, DK: University Press, 386-398.

Jochens, J., 1991. The illicit love visit: An archaeology of Old Norse Sexuality. Journal of the History of Sexuality 3 (1), 357-392.

Jóhannesson, J., 1950. Vápnfirðinga saga. In: J. Jóhannesson, ed. Austfirðinga sögur: Íslenzk fornrit 11. Reykjavík: Hið íslenzka fornritafélag.

Jónsson, E., and Jónsson, F., ed., 1892-96. Hauksbók: Udgiven efter de Arnamagnaanske håndskrifter no. 371, 544 og $675,4^{\circ}$ samt forskellige papirshåndskrifter. Copenhagen: Det Kongelige Nordiske Oldskrift-selskab. 
Kanerva, K., 2013. "Eigi er sá heill, er í augun verkir" Eye Pain as a Literary Motif in Thirteenth and Fourteenth-Century Íslendingasögur. ARV-Nordic Yearbook of Folklore 69, 7-35.

Kanerva, K., 2014. Disturbances of the mind and body: The effects of the living dead in medieval Iceland. In: S. Katajala-Peltomaa and S. Niiranan, eds. Mental (dis)order in the Later Middle ages. Leiden, NL: Brill, 219-242.

Kanerva, K., 2015. Porous bodies, porous minds: Emotions and the supernatural in the Íslendingasögur (ca. 1200-1400). Thesis (PhD). University of Turku.

Karras, R. M., 2003. Marriage and the creation of Kin in the sagas. Scandinavian Studies, 74 (4), 473-490.

Kristjánsson, J., 1972. Um fóstbræðrasögu. Reykjavík: Stofnun Árna Magnússonar.

Künzler, S., 2016. Flesh and word: Reading bodies in Old Norse-Icelandic and early Irish literature. Berlin: Walter de Gruyter.

Larsen, E., ed., 1931. An old icelandic medical miscellany. Oslo: Den Norske Videnskaps-Akademi i Oslo.

Lönnroth, L., 1965. Kroppen som själens spegel - ett motiv $i$ de isländska sagorna. Uppsala, SE: Lychnos Lärdomshistoriska samfundets årsbok.

McDougall, I., 1992. The third instrument of medicine: Some accounts of surgery in medieval Iceland. In: S. Campbell, B. Hall, and D. Klausner, eds. Health, disease and healing in medieval culture. Toronto: Centre for Medieval Studies, University of Toronto, 57-83.

Merkelbach, R., 2019. Monsters in society: Alterity, transgression, and the use of the past medieval Iceland. Berlin: De Gruyter.

Nordal, S., ed., 1933. Egils saga Skalla-Grímssonar: Íslenzk fornrit 2. Reykjavík: Hið íslenzka fornritafélag.

Nordal, S., and Jónsson, G., 1938. Bjarnar saga Hítdælakappa. In: S. Nordal and G. Jónsson, eds. Borgfirðinga sögur: Íslenzk fornrit 3. Reykjavík: Hið íslenzka Fornritafélag.

Pálsson, V., 2015. Language of power: Feasting and gift-giving in medieval Iceland and Its sagas (Islandica 60). Ithaca, NY: Cornell University Press.

Poilvez, M. A., Troll Did It? Trauma as a Paranormal State in the Íslendingasögur. In: Á. Jakobsson and M. Mayburd, eds. Paranormal encounters in Iceland 1150-1400. Berlin: de Gruyter 2020, 71-88.

Reichborn-Kjennerud, I., 1936. Vår eldste medisin til middelalderens slutt. In: I. Reichborn-Kjennerud, F. Grøn, and I. Kobro, eds. Medisinens historie i Norge. Oslo: Grøndahl, 1-97.

Schulman, J. K., 1997. Make me a match: Motifs of betrothal in the sagas of Icelanders. Scandinavian Studies, 69 (3), 296-321.

Sexton, J. P., 2010. Difference and disability: On the logic of naming in the Icelandic sagas. In: J. R. Eyler, ed. Disability in the middle ages. Reconsiderations and reverberations. Farnham, UK: Ashgate, 149-163.

Sexton, J. P., 2020. Atypical bodies: Seeking after meaning in physical difference. In: J. Hsy, T. V. Pearman, and J. R. Eyler, eds. A cultural history of disability in the Middle ages. London: Bloomsbury, 19-34.

Shakespeare, T., 2014. Disability rights and wrongs revisited. London and New York: Routledge.

Simek, R., 2019. Tangible religion: Amulets, illnesses, and the demonic seven sisters. In: K. Wikström af Edholm, P. J. Rova, A. Nordberg, O. Sundqvist, and T. Zachrisson, eds. Myth, Materiality, and lived religion: In Merovingian and Viking Scandinavia. Stockholm: Stockholm University Press, 375-395. 
Sigurðsson, J. V., 2017. Viking friendship: The social bond in Iceland and Norway, C. 900-1300. Ithaca, NY: Cornell University Press.

Tirosh, Y., 2014. The fabulous saga of Guðmundr inn riki: Representation of sexuality in Ljósvetninga saga. Thesis (MA). University of Iceland.

Tirosh, Y., 2019. On the receiving end: The role of scholarship, memory, and genre in constructing Ljósvetninga saga. Thesis (PhD). University of Iceland.

Tulinius, T. H., 2018a. I: 17 Trauma studies. In: J. Glauser, P. Hermann and S. A. Mitchell, eds. Handbook of pre-modern Nordic memory studies: Interdisciplinary approaches. Berlin: de Gruyter, 250-255.

Tulinius, T. H., 2018b. II: 15 Trauma. In: J. Glauser, P. Hermann and S. A. Mitchell, eds. Handbook of pre-modern Nordic memory studies: Interdisciplinary approaches. Berlin: de Gruyter, 495-501.

Walgenbach, E., 2019. Inciting Miracle in Njáls saga: Ámundi hinn blindi's Gift of Sight in Context. Saga-Book 43, 125-136.

Walter, E., 1956. Studien zur Vápnfirðinga Saga. Untersuchungen zur nordischen Literatur- und Sprachgeschichte 1. Halle (Saale), DE: VEB Max Niemeyer Verlag.

Whaley, D. C., and Eliot, D., 1994. A medieval casebook: Hand cures documented in the Icelandic sagas of bishops. Journal of Hand Surgery (British and European Volume) 19 (5), 667-671. Doi: 10.1016/02667681(94)90141-4

porgeirsdóttir, B., 2015. Elskhuginn Egill Skallagrímsson. Skírnir 2, 360-397.

Porgeirsdóttir, B., 2018. Humoral theory in the medieval north: An Old Norse Translation of Epistula Vindiciani in Hauksbók. Gripla 29, 35-66.

Pórólfsson, B. K., and Jónsson, G., 1943. Fóstbrœðra saga. In: B. K. Pórólfsson and G. Jónsson, eds. Vestfirðinga sogur: Íslenzk fornit 6. Reykjavík: Hið íslenzka fornritafélag. 